\title{
Effect of Variations in Dietary Calcium on Renal and Intestinal Calcium-Binding Proteins
}

\author{
MARY JACOB AND JAMES C. M. CHAN \\ Department of Pediatrics, Virginia Commonwealth University's Medical College of Virginia and Children's \\ Medical Center, Richmond, Virginia 23298-0498
}

\begin{abstract}
This study was designed to determine if protein-induced calciuria was related to alterations in the intestinal and renal calcium-binding proteins (CaBP). Weanling Sprague-Dawley rats were fed diets containing low, normal, or high $\mathrm{Ca}$ and protein diets for 2 wk. Twentyfour-h urine and fecal samples were collected before the termination of the study. Plasma, kidney, duodenum, ileum, and femur samples were obtained for selected mineral and CaBP analyses. Growth was significantly depressed on the low protein diets and this was independent of Ca levels. Hypercalcemia, hypercalciuria, and increased renal $\mathrm{CaBP}$ were associated with the high $\mathrm{Ca}$ intakes but not with the high protein diets. It is suggested that in conditions where $\mathrm{Ca}$ intakes are high, the renal $\mathrm{CaBP}$ has a role in $\mathrm{Ca}$ excretion and responds to changes in $\mathrm{Ca}$ concentrations occurring in the distal tubule. No loss of femur Ca was seen in rats on the high protein diets. (Pediatr Res 22: $518-523,1987)$
\end{abstract}

Abbreviations

CaBP, calcium-binding protein

Ca, calcium

P, phosphate

$\mathrm{Na}$, sodium

$\mathbf{K}$, potassium

Cl, chloride

Zn, zinc

$\mathrm{Mg}$, magnesium

PTH, parathyroid hormone

$1,25(\mathrm{OH})_{2} \mathrm{D}_{3}, 1,25$-dihydroxyvitamin $\mathrm{D}_{3}$

TIU, trypsin inhibitor units

Recent experiments have indicated that hypercalciuria frequently follows increased protein intake (1-5), which has been correlated with elevated net acid excretion. It is not resolved whether the hypercalciuria associated with a high protein intake is solely a response due to bone buffering of the endogenous acid production. It is also unclear whether the hypercalciuria is mediated via increased activities of the renal and intestinal calciumbinding proteins. These mechanisms will be carefully evaluated in our study.

The effects of high and low calcium intakes will be explored to determine whether changes in urinary calcium are related to alterations in the calcium-binding proteins of the kidneys and

Received November 17, 1986; accepted June 10, 1987.

Correspondence Dr. James C. M. Chan, Box 498 MCV Station, Richmond, VA 23298-0498.

Supported in part by National Institutes of Health Grants AM-31370, HD-

12335 and National Science Foundation Grant PCM-8402840.

Present address: California State University, Long Beach, CA 90840. intestine as well as the mineral and net acid excretions. In an attempt to clarify further the effects of protein and calcium intakes, this study was designed to investigate the rates of growth and the metabolic adaptations that accompany variations in protein and calcium intakes. The weanling rats are chosen because the effects of dietary intakes on such metabolic changes can be expected to occur at a more rapid rate at this age.

The immature young rat grows very rapidly after birth and it doubles in body weight in approximately 5 days. It is weaned after $3 \mathrm{wk}$ and achieves sexual maturity in 6 to $9 \mathrm{wk}$. This rapid rate of growth and maturation is associated with increased needs for all essential nutrients making the weanling rat more susceptible to nutrient deficiencies (6-8). Therefore the weanling rat was chosen since alterations in dietary calcium and protein at this age would produce metabolic changes at a more rapid rate than at any other age.

\section{MATERIALS AND METHODS}

Thirty-three male, weanling, Sprague-Dawley (Charles River) rats weighing $56 \pm 1 \mathrm{~g}$ were housed individually in metabolic cages with free access to deionized water. The room was maintained on an alternating 12-h light-dark cycle and at an ambient temperature of $22 \pm 2^{\circ} \mathrm{C}$. Three animals were killed on the $1 \mathrm{st}$ day of the experiment to obtain baseline (pretreatment) values. The remaining animals were randomly assigned to eight dietary treatments including an ad libitum and a pair-fed control group. Group IA, the control group, received a diet of normal protein, $20 \mathrm{~g} / 100 \mathrm{~g}$ diet and normal calcium, $5.89 \mathrm{mg} / \mathrm{g}$ diet and was fed ad libitum. Group IB, the control group, received a diet of normal protein $20 \mathrm{~g} / 100 \mathrm{~g}$ diet and normal calcium of $5.89 \mathrm{mg} / \mathrm{g}$ diet and was pair-fed to group VII. Group II, the low protein/low calcium group, received a diet containing $10 \mathrm{~g}$ protein $/ 100 \mathrm{~g}$ diet and $0.3245 \mathrm{mg}$ calcium/g diet. Group III, the low protein/high calcium group, received a diet of $10 \mathrm{~g}$ protein $/ 100 \mathrm{~g}$ diet and $19.64 \mathrm{mg}$ calcium/g diet. Group IV, the normal protein/low calcium group, received a diet of $20 \mathrm{~g}$ protein $/ 100 \mathrm{~g}$ diet and $0.3645 \mathrm{mg}$ calcium $/ \mathrm{g}$ diet. Group $\mathrm{V}$, the normal protein/high calcium group, received a diet of $20 \mathrm{~g}$ protein/100 g diet and $23.12 \mathrm{mg}$ calcium/g diet. Group VI, the high protein/low calcium group, received a diet of $60 \mathrm{~g}$ protein $/ 100 \mathrm{~g}$ diet and 0.3924 $\mathrm{mg}$ calcium/g diet. Group VII, the high protein/high calcium group, received a diet of $60 \mathrm{~g}$ protein $/ 100 \mathrm{~g}$ diet and $22.02 \mathrm{mg}$ calcium $/ \mathrm{g}$ diet.

The three casein levels $(10,20$, and $60 \%)$ were obtained by adjusting the dextrose. Calcium carbonate was added to adjust the $\mathrm{Ca}$ concentrations in the various diets. Monobasic potassium phosphate was used to equalize the phosphate content in all the diets. Standard salt and vitamin mixtures formulated to meet the requirements of growing rats were incorporated in the seven diets (7). All the diets provided $2.5 \mu \mathrm{g}$ vitamin $\mathrm{D}_{3}$ per $100 \mathrm{~g}$ of the diet.

Body weights and food intakes were measured daily. During 
the 2nd wk of the study, the animals were transferred to Nalgene metabolic cages and after equilibration, two separate 24-h urine and feces samples were collected. The samples were stored at $-70^{\circ} \mathrm{C}$ until analysis. At the end of the $2 \mathrm{nd} w \mathrm{k}$, the animals were anesthetized using Metofane and blood was obtained by cardiac puncture. The plasma was separated and stored at $-70^{\circ}$ $\mathrm{C}$. The right kidneys and left femurs were taken for mineral determinations. Urine was analyzed for net acid excretion, i.e. titratable acidity and ammonium (9). Plasma and urine samples were measured for $\mathrm{Na}, \mathrm{Ca}$, and $\mathrm{P}$. The dried kidneys and femurs were wet-ashed for $\mathrm{Ca}$ determination by atomic absorption spectrophotometry (10). Na and $\mathrm{P}$ were analyzed by standard methods $(11,12)$. Fecal samples were dried and wet-ashed for mineral analyses.

\section{PREPARATION AND PROCESSING OF INTESTINAL AND KIDNEY CALCIUM-BINDING PROTEIN}

The proximal duodenum $(0-15 \mathrm{~cm}$ from the pyloric valve) and $10 \mathrm{~cm}$ of the ileum from the cecum were carefully measured, quickly excised, and rinsed with $6 \mathrm{ml}$ saline containing the protease inhibitors aprotinin $(0.14 \mathrm{TIU} / \mathrm{ml})$ and phenylmethylsulfonylfluoride $(0.5 \mu \mathrm{g} / \mathrm{ml})$. The segments were blotted, immediately frozen in liquid $\mathrm{N}_{2}$, and stored individually at $-70^{\circ} \mathrm{C}$ until processed. Each frozen segment was thawed in $3 \mathrm{ml} 4^{\circ} \mathrm{C}$ buffer ( $10 \mathrm{mM}$ Tris- $\mathrm{HCl}, \mathrm{pH} 7.2,1 \mathrm{mM}$ 2-mercaptoethanol, 5 $\mathrm{mM}$ benzamidine, and protease inhibitors $-2.0 \mathrm{mM}$ phenylmethylsulfonylfluoride and $0.22 \mathrm{TIU}$ aprotinin $/ \mathrm{ml}$ ) and homogenized using a Tissuemizer at $30,000 \mathrm{rpm}$ for $12 \mathrm{~s}$ at $4^{\circ} \mathrm{C}$. The homogenate was centrifuged at $40,000 \mathrm{rpm}$ for $20 \mathrm{~min}$, and the supernatant fraction was stored at $-70^{\circ} \mathrm{C}$. The amount of immunoreactive calcium-binding protein in the $40,000 \times g$ supernatant fraction was measured by radial immunodiffusion using antiserum generated in rabbits to a purified preparation of rat intestinal calcium-binding protein (13). The calcium-binding protein antigen and standards used in these assays were prepared as described previously (13) and further purified by a second preparative slab gel electrophoresis. In this step, $0.1 \mathrm{mM}$ EDTA was incorporated in the electrode buffer to change the $R_{f}$ of the protein from 0.25 to 0.75 . The soluble protein in the supernatant fraction was determined by the Lowry procedure (14).

The left kidneys were carefully and quickly excised, decapsulated and immediately frozen in liquid $\mathrm{N}_{2}$ and stored at $-70^{\circ} \mathrm{C}$ for the determination of renal calcium-binding protein. Antiserum against rat renal CaBP was obtained from New Zealand White rabbits injected with the purified renal CaBP (15). The radioimmunoassay method used to quantitate rat renal $\mathrm{CaBP}$ has been described in detail previously $(15,16)$.

Statistical analysis. Data are presented as the mean $\pm 1 \mathrm{SD}$, the mean \pm SEM, or the mean and the range. Mean differences between the study groups were assessed using one-way analysis of variance (17). Tukey's studentized range test and the Student's $t$ test were performed to detect differences among means which were shown to be significant by the $F$ test (18). Correlation coefficients between plasma $\mathrm{Ca}$, urine $\mathrm{Na}$ and $\mathrm{Ca}$, and renal $\mathrm{CaBP}$ were determined (18).

\section{RESULTS}

Figure 1 shows the gain in body weights of the eight groups of rats during the 14-day experimental period. The means on day 13 for all groups were compared. Animals on the low protein diets gained significantly ( $p \leq 0.01$ ) less weight than either the normal or high protein fed groups. The different $\mathrm{Ca}$ levels in the diets apparently did not affect the weight gains.

Tables $1-3$ show the mean plasma, urine, and feces mineral concentrations of the 8 groups. Rats on the high $\mathrm{Ca}$ diets had increased plasma $\mathrm{Ca}$ and decreased levels of $\mathrm{P}$, as compared to their respective low Ca controls (Table 1). Based on Tukey's test,

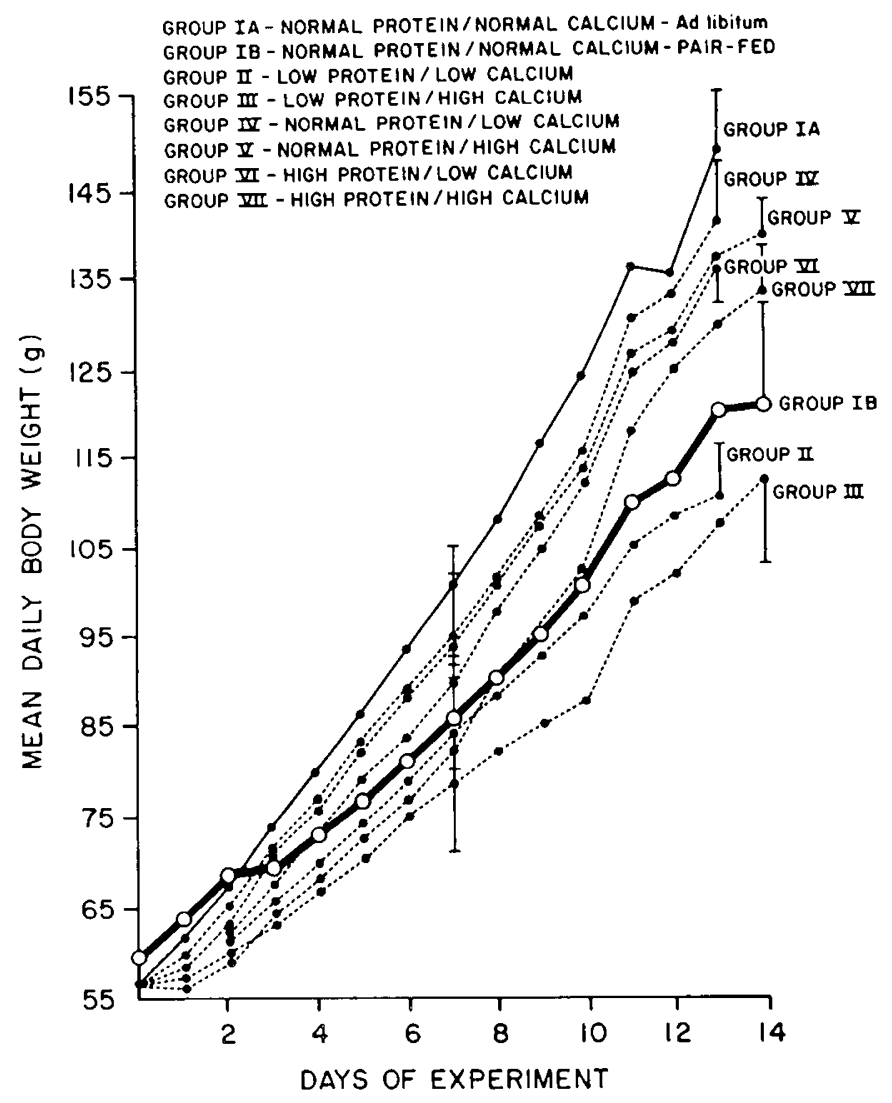

Fig. 1. Effect of varying dietary calcium and protein on growth of rats. Mean \pm SEM, vertical bars represent SEM.

Table 1. Effect of dietary calcium and protein on selected plasma minerals (mean $\pm S D$ )

\begin{tabular}{|c|c|c|c|c|c|}
\hline & \multirow[b]{3}{*}{ Treatment } & \multirow[b]{3}{*}{$n$} & \multicolumn{3}{|c|}{ Mean } \\
\hline & & & $\mathrm{Na}$ & $\mathrm{Ca}$ & iP \\
\hline & & & $(\mathrm{mm} /$ liter $)$ & $(\mathrm{mg} / \mathrm{dl})$ & $(\mathrm{mg} / \mathrm{dl})$ \\
\hline \multirow[t]{2}{*}{ IA } & normal protein/ & 3 & 118.20 & 10.60 & 9.88 \\
\hline & $\begin{array}{l}\text { normal Ca (ad } \\
\text { libitum }\end{array}$ & & \pm 17.26 & \pm 0.63 & \pm 1.82 \\
\hline \multirow[t]{2}{*}{ IB } & normal protein/ & 3 & 130.40 & 9.70 & 8.46 \\
\hline & $\begin{array}{l}\text { normal Ca } \\
\text { (pair-fed) }\end{array}$ & & \pm 4.43 & \pm 0.45 & \pm 1.27 \\
\hline \multirow[t]{2}{*}{ II } & low protein/low & 4 & 137.00 & 7.70 & 10.85 \\
\hline & $\mathrm{Ca}$ & & \pm 8.30 & \pm 0.51 & \pm 1.75 \\
\hline \multirow[t]{2}{*}{ III } & low protein/ & 4 & 130.60 & $11.55^{*}$ & $6.73 \dagger$ \\
\hline & high $\mathrm{Ca}$ & & \pm 2.04 & \pm 0.70 & \pm 0.60 \\
\hline \multirow[t]{2}{*}{ IV } & normal protein/ & 4 & 136.50 & 6.93 & 9.87 \\
\hline & low $\mathrm{Ca}$ & & \pm 3.12 & \pm 0.77 & \pm 1.21 \\
\hline \multirow[t]{2}{*}{$\mathrm{V}$} & normal protein/ & 4 & 133.70 & $12.95^{*}$ & $6.37 \dagger$ \\
\hline & high $\mathrm{Ca}$ & & \pm 2.66 & \pm 0.86 & \pm 0.64 \\
\hline \multirow[t]{2}{*}{ VI } & high protein/. & 4 & 141.00 & 7.38 & 9.81 \\
\hline & low $\mathrm{Ca}$ & & \pm 9.15 & \pm 0.36 & \pm 1.21 \\
\hline \multirow[t]{2}{*}{ VII } & high protein/ & 4 & 137.30 & $10.40 \dagger$ & $6.34 \dagger$ \\
\hline & high $\mathrm{Ca}$ & & \pm 1.61 & \pm 1.59 & \pm 0.10 \\
\hline
\end{tabular}

${ }^{*} p<0.001$, significantly different from the low Ca controls

$\dagger p<0.01$, significantly different from the low Ca controls.

no differences were seen when groups III and VII were compared with group IB.

Urinary $\mathrm{Ca}$ was elevated on the high $\mathrm{Ca}$ diets and $\mathrm{P}$, were significantly ( $p \leq 0.001)$ reduced as compared to the appropriate controls as well as to those fed normal Ca (Table 2).

Fecal $\mathrm{Ca}$ and $\mathrm{P}$ were significantly $(p \leq 0.01)$ increased by the high $\mathrm{Ca}$ diets (Table 3 ). 
Table 2. Effect of dietary calcium and protein on urine excretion of selected minerals (mean $\pm S D$ )

\begin{tabular}{|c|c|c|c|c|c|c|}
\hline & \multirow[b]{3}{*}{ Treatment } & \multirow[b]{3}{*}{$n$} & \multirow{3}{*}{$\begin{array}{c}\mathrm{Na} \\
(\mathrm{mEq} \\
24 \mathrm{~h})\end{array}$} & \multicolumn{2}{|c|}{ Mean } & \multirow{3}{*}{$\begin{array}{c}\mathrm{NAE} \\
\mu \mathrm{Eq} / \mathrm{min} \\
\mathrm{kg} \\
\text { body wt }\end{array}$} \\
\hline & & & & $\mathrm{Ca}$ & iP & \\
\hline & & & & \multicolumn{2}{|c|}{$(\mathrm{mg} / 24 \mathrm{~h})$} & \\
\hline \multirow[t]{2}{*}{ IA } & normal protein/ & 2 & 1.03 & 0.41 & 3.71 & 2.70 \\
\hline & $\begin{array}{l}\text { normal } \mathrm{Ca}(\mathrm{ad} \\
\text { libitum) }\end{array}$ & & \pm 0.47 & \pm 0.17 & \pm 4.78 & \pm 1.23 \\
\hline \multirow[t]{2}{*}{ IB } & normal protein/ & 3 & 0.85 & 0.17 & 9.70 & 1.68 \\
\hline & $\begin{array}{l}\text { normal Ca } \\
\text { (pair-fed) }\end{array}$ & & \pm 0.08 & \pm 0.05 & \pm 3.65 & \pm 1.33 \\
\hline \multirow[t]{2}{*}{ II } & low protein/low & 4 & 1.66 & 0.20 & 27.08 & 3.83 \\
\hline & $\mathrm{Ca}$ & & \pm 0.21 & \pm 0.09 & \pm 15.09 & \pm 0.73 \\
\hline \multirow[t]{2}{*}{ III } & low protein/ & 4 & $0.23^{*}$ & $9.97 \dagger$ & $0.05^{*}$ & 4.94 \\
\hline & high $\mathrm{Ca}$ & & \pm 0.15 & \pm 3.61 & \pm 0.01 & \pm 1.40 \\
\hline \multirow[t]{2}{*}{ IV } & normal protein/ & 4 & 1.04 & 0.07 & 23.10 & 2.08 \\
\hline & low $\mathrm{Ca}$ & & \pm 0.14 & \pm 0.03 & \pm 3.48 & \pm 1.30 \\
\hline \multirow[t]{2}{*}{ V } & normal protein/ & 4 & $0.47 \dagger$ & $13.19^{*}$ & $0.05^{*}$ & 1.95 \\
\hline & high $\mathrm{Ca}$ & & \pm 0.21 & \pm 4.19 & \pm 0.01 & \pm 1.16 \\
\hline \multirow[t]{2}{*}{ VI } & high protein/ & 4 & 0.85 & 0.11 & 31.48 & 16.50 \\
\hline & low $\mathrm{Ca}$ & & \pm 0.07 & \pm 0.05 & \pm 4.91 & \pm 2.92 \\
\hline \multirow[t]{2}{*}{ VII } & high protein/ & 4 & $0.45^{*}$ & $14.60^{*}$ & $0.08^{*}$ & 3.00 \\
\hline & high Ca & & \pm 0.09 & \pm 4.70 & \pm 0.03 & \pm 0.56 \\
\hline
\end{tabular}

Table 3. Effect of dietary calcium and protein on selected fecal mineral excretion (mean $\pm S D$ )

\begin{tabular}{|c|c|c|c|c|}
\hline & \multirow[b]{3}{*}{ Treatment } & \multirow[b]{3}{*}{$n$} & \multicolumn{2}{|c|}{ Mean } \\
\hline & & & $\mathrm{Ca}$ & iP \\
\hline & & & \multicolumn{2}{|c|}{$(\mathrm{mg} / 24 \mathrm{~h})$} \\
\hline IA & $\begin{array}{l}\text { normal protein/ } \\
\text { normal Ca (ad li- } \\
\text { bitum) }\end{array}$ & 3 & $\begin{array}{r}34.56 \\
\pm 12.36\end{array}$ & $\begin{array}{r}10.00 \\
\pm 2.73\end{array}$ \\
\hline IB & $\begin{array}{l}\text { normal protein/ } \\
\text { normal Ca (pair } \\
\text { fed) }\end{array}$ & 3 & $\begin{array}{r}37.19 \\
+26.29\end{array}$ & $\begin{array}{r}13.59 \\
\pm 4.74\end{array}$ \\
\hline II & $\begin{array}{l}\text { low protein/low } \\
\mathrm{Ca}\end{array}$ & 4 & $\begin{array}{r}4.49 \\
\pm 1.31\end{array}$ & $\begin{array}{r}6.70 \\
\pm 2.42\end{array}$ \\
\hline III & $\begin{array}{l}\text { low protein/high } \\
\mathrm{Ca}\end{array}$ & 4 & $\begin{array}{l}145.11^{*} \\
\pm 27.67\end{array}$ & $\begin{array}{r}15.67 \\
\pm 13.02\end{array}$ \\
\hline IV & $\begin{array}{l}\text { normal protein/ } \\
\text { low } \mathrm{Ca}\end{array}$ & 4 & $\begin{array}{r}5.35 \\
\pm 2.03\end{array}$ & $\begin{array}{r}3.24 \\
\pm 0.69\end{array}$ \\
\hline V & $\begin{array}{l}\text { normal protein/ } \\
\text { high } \mathrm{Ca}\end{array}$ & 4 & $\begin{array}{l}219.10^{\dagger} \\
\pm 15.66\end{array}$ & $\begin{array}{l}18.78^{*} \\
\pm 5.68\end{array}$ \\
\hline VI & $\begin{array}{l}\text { high protein/low } \\
\mathrm{Ca}\end{array}$ & 4 & $\begin{array}{r}3.01 \\
\pm 0.84\end{array}$ & $\begin{array}{r}1.71 \\
\pm 0.28\end{array}$ \\
\hline VII & $\begin{array}{l}\text { high protein/high } \\
\mathrm{Ca}\end{array}$ & 4 & $\begin{array}{l}135.85^{*} \\
\pm 25.84 \\
\end{array}$ & $\begin{array}{l}24.36 \dagger \\
\pm 5.03\end{array}$ \\
\hline
\end{tabular}

Table 4 presents the mean dry weights and mineral content of the right kidneys of rats on the various dietary treatments. High $\mathrm{Ca}$ diets significantly $(p \leq 0.01)$ increased the Ca content of the kidneys. There was an increase in the dry weight of the kidneys associated with the elevated level of dietary protein. This difference was still evident in the high protein-fed groups when the data were expressed on a body weight basis.

The mean femur mineral concentrations of all the groups are shown in Table 5. The femur dry weights of the low Ca fed animals were significantly $(p \leq 0.01)$ less than those obtained from the high $\mathrm{Ca}$ controls. The bone weights were unaffected by
Table 4. Effect of dietary calcium and protein on dry wt and mineral content of right kidneys (mean $\pm S D$ )

\begin{tabular}{|c|c|c|c|c|c|}
\hline & \multirow[b]{3}{*}{ Treatment } & \multirow[b]{3}{*}{$n$} & \multirow{3}{*}{$\begin{array}{l}\text { Dry wt } \\
(\mathrm{g})\end{array}$} & \multicolumn{2}{|c|}{ Mean } \\
\hline & & & & $\mathrm{Ca}$ & iP \\
\hline & & & & $(\mathrm{mg} / \mathrm{g} \overline{\mathrm{d}}$ & wt) \\
\hline \multirow[t]{2}{*}{ IA } & normal protein/ & 3 & 0.152 & 420.36 & 8.95 \\
\hline & $\begin{array}{l}\text { normal } \mathrm{Ca}(\mathrm{ad} \\
\text { libitum) }\end{array}$ & & \pm 0.019 & \pm 33.63 & \pm 1.02 \\
\hline \multirow[t]{2}{*}{ IB } & normal protein/ & 3 & 0.141 & 394.00 & 7.62 \\
\hline & $\begin{array}{l}\text { normal Ca } \\
\text { (pair-fed) }\end{array}$ & & \pm 0.026 & \pm 10.91 & \pm 2.82 \\
\hline \multirow[t]{2}{*}{ II } & low protein/low & 4 & 0.116 & 377.90 & 7.41 \\
\hline & $\mathrm{Ca}$ & & \pm 0.015 & \pm 21.35 & \pm 2.65 \\
\hline \multirow[t]{2}{*}{ III } & low protein/ & 4 & 0.103 & $585.80^{*}$ & 9.20 \\
\hline & high $\mathrm{Ca}$ & & 0.018 & \pm 29.54 & \pm 1.20 \\
\hline \multirow[t]{2}{*}{ IV } & normal protein/ & 4 & 0.153 & 326.20 & 6.85 \\
\hline & low $\mathrm{Ca}$ & & \pm 0.028 & \pm 16.25 & \pm 1.87 \\
\hline \multirow[t]{2}{*}{$\mathrm{V}$} & normal protein/ & 4 & 0.142 & $628.60 \dagger$ & 8.92 \\
\hline & high $\mathrm{Ca}$ & & \pm 0.015 & \pm 143.39 & \pm 1.81 \\
\hline \multirow[t]{2}{*}{ VI } & high protein/ & 4 & 0.187 & 312.20 & 11.19 \\
\hline & low $\mathrm{Ca}$ & & 0.018 & \pm 9.80 & \pm 2.02 \\
\hline \multirow[t]{2}{*}{ VII } & high protein/ & 4 & 0.177 & $470.00 \dagger$ & 8.14 \\
\hline & high $\mathrm{Ca}$ & & \pm 0.015 & \pm 61.56 & \pm 1.93 \\
\hline
\end{tabular}

$* p<0.001$, significantly different from the low Ca controls.

$\dagger p<0.01$, significantly different from the low Ca controls.

Table 5. Effect of dietary calcium and protein on dry wt and mineral content of left femurs (mean $\pm S D$ )

\begin{tabular}{|c|c|c|c|c|c|}
\hline & \multirow[b]{3}{*}{ Treatment } & \multirow[b]{3}{*}{$n$} & \multirow{3}{*}{$\begin{array}{c}\text { Dry wt } \\
(\mathrm{g})\end{array}$} & \multicolumn{2}{|c|}{ Mean } \\
\hline & & & & $\mathrm{Ca}$ & iP \\
\hline & & & & \multicolumn{2}{|c|}{$(\mathrm{mg} / \mathrm{g}$ dry $w \mathrm{t})$} \\
\hline IA & $\begin{array}{l}\text { normal protein/ } \\
\text { normal Ca (ad } \\
\text { libitum) }\end{array}$ & 3 & $\begin{array}{r}0.151 \\
\pm 0.009\end{array}$ & $\begin{array}{r}205.70 \\
\pm 6.65\end{array}$ & $\begin{array}{r}68.20 \\
\pm 15.64\end{array}$ \\
\hline IB & $\begin{array}{l}\text { normal protein/ } \\
\text { normal Ca (pair } \\
\text { fed) }\end{array}$ & 3 & $\begin{array}{r}0.139 \\
\pm 0.018\end{array}$ & $\begin{array}{r}211.97 \\
\pm 2.65\end{array}$ & $\begin{array}{r}90.50 \\
\pm 6.28\end{array}$ \\
\hline II & $\begin{array}{l}\text { low protein/low } \\
\mathrm{Ca}\end{array}$ & 4 & $\begin{array}{r}0.087 \\
\pm 0.021\end{array}$ & $\begin{array}{r}203.25 \\
\pm 35.30\end{array}$ & $\begin{array}{r}71.20 \\
\pm 4.48\end{array}$ \\
\hline III & $\begin{array}{l}\text { low protein/ } \\
\text { high Ca }\end{array}$ & 4 & $\begin{aligned} & 0.132^{*} \\
& \pm 0.030\end{aligned}$ & $\begin{array}{r}220.32 \\
\pm 22.38\end{array}$ & $\begin{array}{r}78.30 \\
\pm 8.09\end{array}$ \\
\hline IV & $\begin{array}{l}\text { normal protein/ } \\
\text { low } \mathrm{Ca}\end{array}$ & 4 & $\begin{array}{r}0.083 \\
\pm 0.015\end{array}$ & $\begin{array}{r}198.54 \\
\pm 9.01\end{array}$ & $\begin{array}{r}76.80 \\
\pm 11.69\end{array}$ \\
\hline V & $\begin{array}{l}\text { normal protein/ } \\
\text { high } \mathrm{Ca}\end{array}$ & 4 & $\begin{aligned} & 0.140 \dagger \\
& \pm 0.014\end{aligned}$ & $\begin{array}{r}215.94 \\
\pm 13.97\end{array}$ & $\begin{array}{r}75.80 \\
\pm 10.00\end{array}$ \\
\hline VI & $\begin{array}{l}\text { high protein/ } \\
\text { low Ca }\end{array}$ & 4 & $\begin{array}{r}0.090 \\
\pm 0.013\end{array}$ & $\begin{array}{r}197.54 \\
\pm 9.25\end{array}$ & $\begin{array}{r}79.80 \\
\pm 7.18\end{array}$ \\
\hline VII & $\begin{array}{l}\text { high protein/ } \\
\text { high } \mathrm{Ca}\end{array}$ & 4 & $\begin{array}{r}0.139 \dagger \\
\pm 0.018 \\
\end{array}$ & $\begin{array}{l}230.73^{*} \\
\pm 19.86\end{array}$ & $\begin{array}{r}103.80 \\
\pm 11.11 \\
\end{array}$ \\
\hline
\end{tabular}

$* p<0.05$, significantly different from the low Ca controls.

$\dagger p<0.01$, significantly different from the low $\mathrm{Ca}$ controls.

the protein levels. The femur $\mathrm{Ca}$ content tended to be higher for all the animals on the high $\mathrm{Ca}$ diets though the differences were not statistically significant.

The mean CaBPs from the duodenum, ileum and kidney are summarized in Table 6. Duodenal and ileal CaBPs were reduced in rats fed the high $\mathrm{Ca}$ diets compared to the appropriate low $\mathrm{Ca}$ controls. However, the renal CaBP was significantly $(p \leq 0.05)$ increased in animals on the high $\mathrm{Ca}$ diets containing low or normal protein as compared to the low $\mathrm{Ca}$ fed controls. No 
Table 6. Effect of dietary calcium and protein on duodenal, ileal, and renal CaBP (mean $\pm S D)$

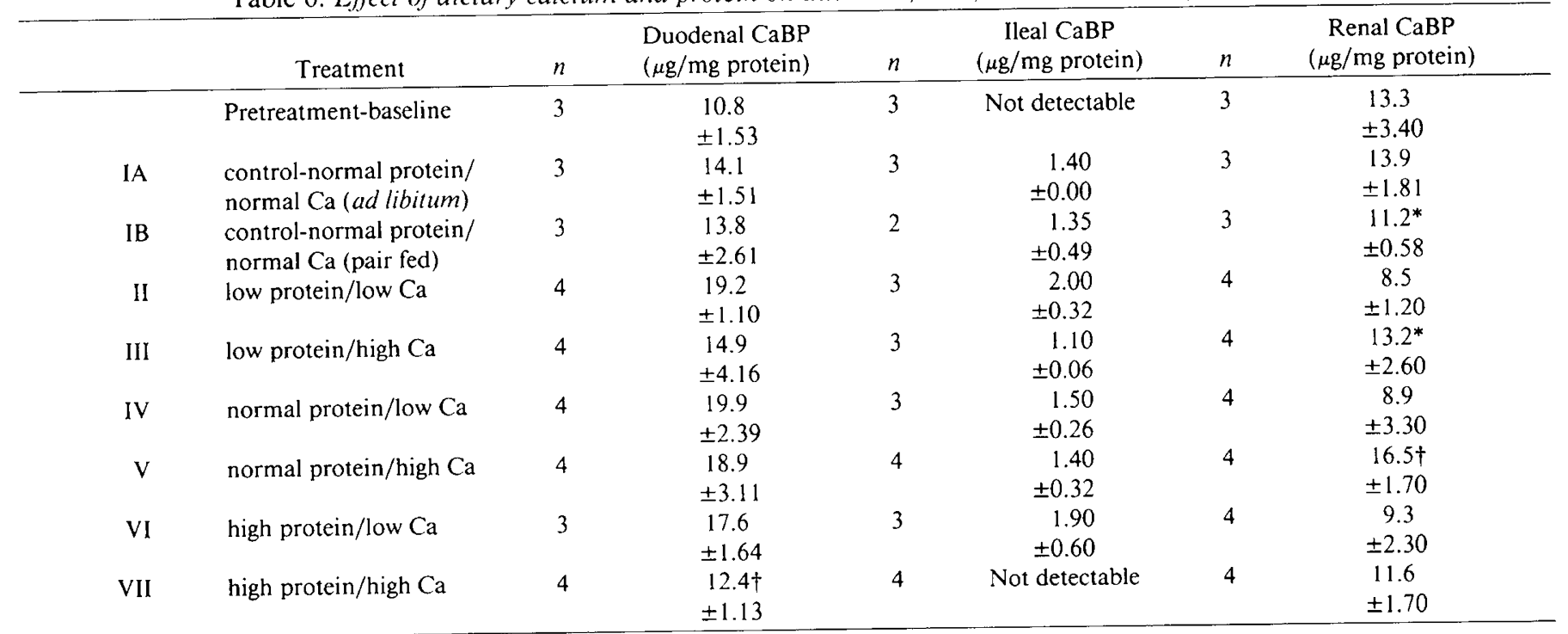

${ }^{*} p \leq 0.05$, significantly different from the low Ca controls.

$\dagger p \leq 0.01$, significantly different from the low Ca controls.

differences were detected between the high $\mathrm{Ca}$ groups containing either the low or high protein and the normal protein-normal $\mathrm{Ca}$ groups. Plasma and urine $\mathrm{Ca}$ concentrations were positively correlated $(r=0.75,0.56)$ with renal CaBP $(p \leq 0.001)$ (Figs. 2 and 3 ). In contrast, negative correlations were observed between urine $\mathrm{Na}$ and the renal CaBP $(r=-0.56, p \leq 0.002)$ (Fig. 4) and urinary $\mathrm{Na}$ and urine $\mathrm{Ca}(r=-0.69, p \leq 0.0001)$ (Fig. 5). The alterations in the duodenal, ileal, and renal $\mathrm{CaBPs}$ were apparently not influenced by the protein intakes.

\section{DISCUSSION}

The results of this study show that growth is dependent on protein intake. The slower weight gain in rats fed the $10 \%$ protein diets indicated that these diets were inadequate to support optimum growth in the weanling rats. Plasma, urine, feces, kidney, and femur $\mathrm{Ca}$ were directly related to dietary $\mathrm{Ca}$ and were not affected by the protein levels in the diet. It has been documented that increasing the protein intake produces a rise in urinary $\mathrm{Ca}$ excretion in several species $(1-5,19-23)$. In this study, the dietary $\mathrm{P}$ concentration was held constant at $0.48 \%$. However, with the alterations in $\mathrm{Ca}$ levels, the $\mathrm{Ca}: \mathrm{P}$ ratios were $0.07,1.2$, and 4.4 for the low, normal, and high Ca diets, respectively. High dietary $C a$ resulted in increasing fecal $P$ and decreasing urinary $P$ excretions. The expected protein-associated hypercalciuria was not observed nor was there any decrease in bone Ca possible because the dietary $\mathrm{Ca}$ and $\mathrm{P}$ concentrations were adequate to meet the needs of the growing rat. Bell et al. (22) reported that although calciuria was seen in high protein fed adult rats, there was no change in overall $\mathrm{Ca}$ balance or bone resorption. In the young, fast growing rat, Howe and Beecher (24) showed that increasing the dietary protein did not result in hypercalciuria.

The changes in $\mathrm{P}$ excretion and plasma $\mathrm{P}$ concentrations may be attributed to the well-established parathyroid hormone effect. The hypercalcemia occurring in response to feeding the high $\mathrm{Ca}$ diets presumably depressed endogenous PTH activity thereby increasing tubular $\mathrm{P}$ reabsorption. Conversely, the low $\mathrm{Ca}$ diet would stimulate PTH secretion which inhibited $\mathrm{P}$ reabsorption. Anderson and Draper (25) demonstrated a phosphaturia in rats fed a low $\mathrm{Ca}: \mathrm{P}$ ratio diet.

It was of interest that although the $\mathrm{Na}$ contents in all the diets were very similar, an inverse relationship was observed between urinary $\mathrm{Na}$ and $\mathrm{Ca}$ excretion. It is well known that the renal handling of $\mathrm{Ca}$ and $\mathrm{Na}$ are interdependent (26). Micropuncture

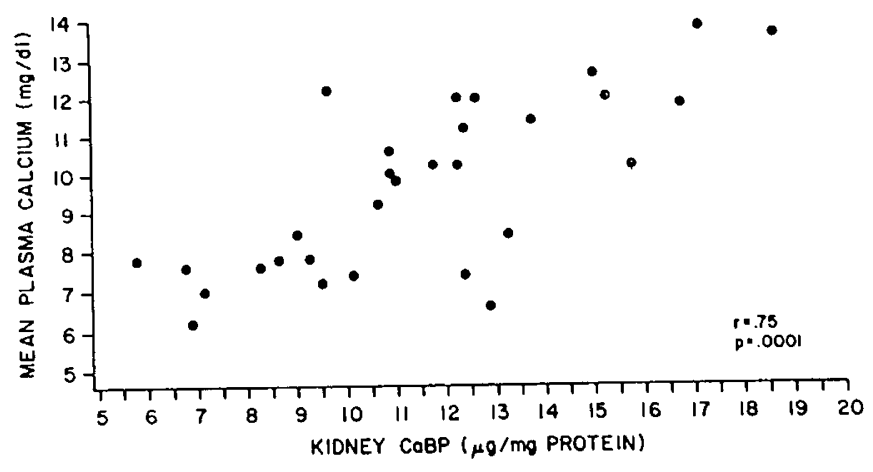

Fig. 2. Relationship between mean plasma calcium and kidney $\mathrm{CaBP}$.

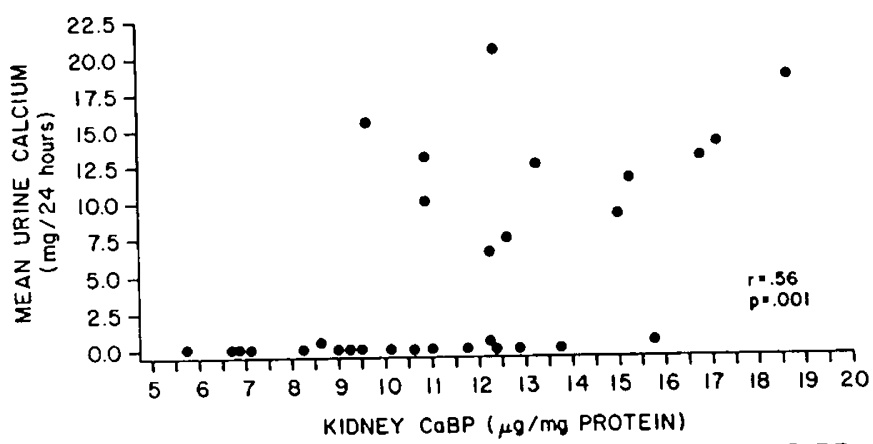

Fig. 3. Relationship between mean urine calcium and kidney CaBP.

studies have illustrated this interdependence of $\mathrm{Ca}$ and $\mathrm{Na}$ reabsorption primarily in the proximal tubule. In contrast, it has been suggested that $\mathrm{Ca}$ reabsorption is dissociated from $\mathrm{Na}$ in the distal tubule which is believed to be the site where urinary $\mathrm{Ca}$ excretion is finely controlled (27). Breslau et al. (28) reported a hypercalciuric response in normal human subjects given a $10-$ day oral load of $\mathrm{Na}$. This $\mathrm{Na}$ loading was associated with both an increase in renal synthesis of $1,25(\mathrm{OH})_{2} \mathrm{D}_{3}$ and intestinal absorption of $\mathrm{Ca}$. Also PTH has been shown to lower $\mathrm{Ca}$ excretion by enhancing distal $\mathrm{Ca}$ reabsorption disproportionately to that of $\mathrm{Na}(29)$. Since $\mathrm{Ca}$ transport by kidney cells is regulated 


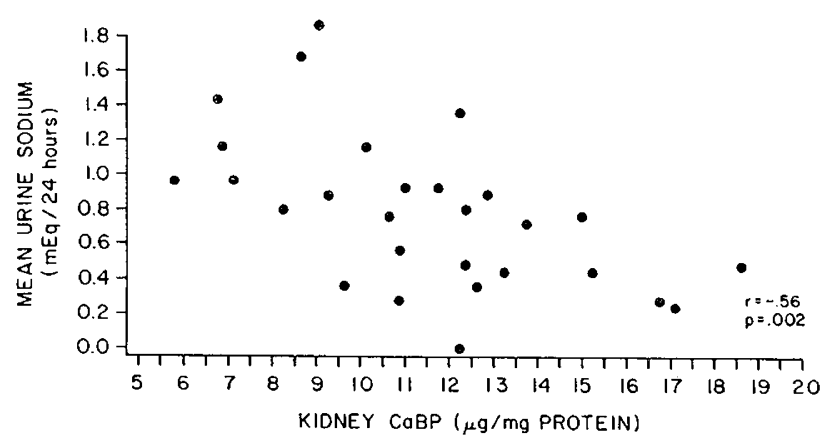

Fig. 4. Relationship between mean urine sodium and kidney CaPB.

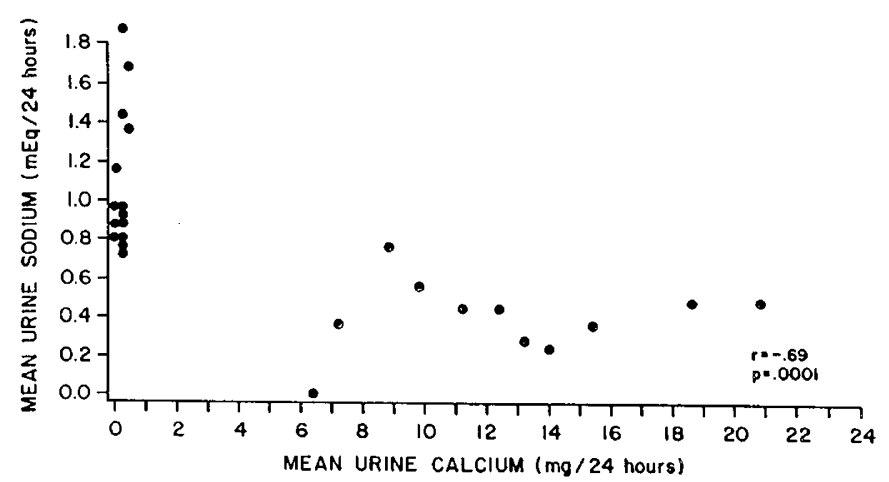

Fig. 5. Relationship between mean urine sodium and urine calcium.

by ionic and endocrine factors, it is possible that any perturbation in the $\mathrm{Ca}: \mathrm{Na}$ ratios in the tubular fluid could affect reabsorption and excretion along the tubular sites.

It has been shown that renal $\mathrm{CaBP}$ is present in distal convoluted tubule cells $(15,30-33)$. There is evidence that this CaBP may be influenced either by $1,25(\mathrm{OH})_{2} \mathrm{D}_{3}$ or $\mathrm{Ca}$ or $\mathrm{Na}(32,34$, $35)$. In the present study, a direct correlation was observed between renal $\mathrm{CaBP}$ and the high $\mathrm{Ca}$ intakes which resulted in hypercalcemia as well as distinct hypercalciuria. The rats ingesting excessively high dietary $\mathrm{Ca}$ exhibited significantly reduced urinary $\mathrm{Na}$ excretion and high renal $\mathrm{CaBP}$. This is unlike previous findings (35) in which there was a $50 \%$ decrease in renal $\mathrm{CaBP}$ in the Na-deficient rats as compared with the control animals. The previous dietary $\mathrm{Na}$ and $\mathrm{Ca}$ contents were 0.02 and $0.53 \%$, respectively as compared with the $0.1 \% \mathrm{Na}$ and $2 \% \mathrm{Ca}$ used in the present study. The previous study (35) suggested that under conditions of severe sodium deprivation, renal $\mathrm{CaBP}$ is indeed markedly reduced. In the present study, rats received moderate amounts of dietary sodium. Thus, these variations in dietary $\mathrm{Na}$ and $\mathrm{Ca}$ components most probably contributed to the different results obtained. Also, it is likely that the high dietary Ca concentration in the present study may have been the predominant factor regulating the synthesis of the renal CaBP which was independent of dietary $\mathrm{Na}$ concentrations. In agreement with the findings of Thomasset et al (32), the $1,25(\mathrm{OH})_{2} \mathrm{D}_{3^{\prime}}$ dependent duodenal $\mathrm{CaBP}$ in the current investigation increased in response to the feeding of low $\mathrm{Ca}$ diets while it decreased on the high $\mathrm{Ca}$ diets.

In summary, the evidence suggests that the increase in renal $\mathrm{CaBP}$ is a response to the hypercalcemia induced by the high $\mathrm{Ca}$ diets and that $\mathrm{CaBP}$ is involved in $\mathrm{Ca}$ excretion. Since independent transport processes for $\mathrm{Ca}$ and $\mathrm{Na}$ have been suggested in the distal nephron, it is possible that several physiological adjustments were made in Ca excretion at this site including regulation by renal $\mathrm{CaBP}$. As the final concentration of $\mathrm{Ca}$ in the urine is determined by what occurs at the distal site, any alterations in $\mathrm{Ca}$ and $\mathrm{Na}$ will affect the outcome. In the case of the high $\mathrm{Ca}$ diets, the quantity of $\mathrm{Ca}$ delivered to the distal tubule was proportionately high relative to $\mathrm{Na}$ and it is possible that the normalization of this $\mathrm{Ca}$ concentration was attempted by increasing excretion.

Acknowledgments. The secretarial assistance of Betty Timozek and Virginia Murrell and research assistance of Faith Sheffer are much appreciated. M. Elizabeth Bruns, Ph.D. and Sylvia Christakos, Ph.D. provided analysis of calcium-binding protein.

\section{REFERENCES}

1. Linkswiler HM, Zemel MB, Hegsted M, Shuette S 1981 Protein-induced hypercalciuria. Fed Proc 40:2429-2433

2. Lutz L 1984 Calcium balance and acid base status of uremia as affected by increased protein intake and by sodium bicarbonate ingestion. Am J Clin Nutr 39:281-288

3. Spencer H, Kramer L, DeBartolo M, Norris C, Osis D 1983 Further studies of the effect of a high protein diet as meat on calcium metabolism. Am J Clin Nutr 37:924-929

4. Walker R, Linkswiler H 1972 Calcium retention in the adult human male as affected by protein intake. J Nutr 102:1297-1302

5. Whiting SJ, Draper HH 1980 The role of sulfate in the calciuria of high protein diets in adult rats. $\mathbf{J}$ Nutr 110:212-222

6. Young MG, Mickelsen O 1974 Laboratory animals in nutritional research. In: Gay WI (ed) Methods of Animal Experimentation, Vol 5. Academic Press, New York, pp 1-10

7. National Research Council 1978. Nutrient Requirements of the Laboratory Rat. National Academy of Sciences, Washington, DC, pp 7-37

8. Dallman PR 1986 Biochemical basis for the manifestations of iron deficiency. Ann Rev Nutr 6:13-40.

9. Chan JCM 1972 The rapid determination of urinary titratable acid and ammonium and evaluation of freezing as a method of preservation. Clin Biochem 5:94-98

10. Analytical Methods for Atomic Absorption Spectrophotometry 1982. The Perkin-Elmer Corporation, Norwalk, CT, pp BC-1-BC-9

11. Beckman System E4A Electrolyte Operating Manual 1984. Beckman Instruments, Inc, Brea, CA, pp 8.5-8.42

12. Baginski ES, Foa PP, Zak B 1967 Determination of phosphate: study of labile organic phosphate interference. Clin Chim Acta 15:155-158

13. Bruns ME, Meyer Jr RA, Meyer MH 1984 Low levels of intestinal vitamin Ddependent calcium-binding protein in juvenile $\mathrm{x}$-linked hypophosphatemic mice. Endocrinology 15:1459-1463

14. Lowry OH, Rosebrough NJ, Farr AL, Randall RJ 1951 Protein measurement with the Folin phenol reagent. J Biol Chem 193:265-275

15. Pansini AR, Christakos S 1984 Vitamin D-dependent calcium-binding protein in rat kidney. Purification and physicochemical and immunological characteristics. J Biol Chem 259:9735-9741

16. Sonnenberg J, Pansini AR, Christakos S 1984 Vitamin D dependent calcium binding protein in rat kidney: development of radioimmunoassay, tissue distribution, and immunologic identification. Endocrinology 115:640-648

17. Bhattacharyya GK, Johnson RA 1977 Statistical Concepts and Methods. John Wiley and Sons, New York, pp 453-504

18. SAS User's Guide: Statistics 1982 ed. SAS Institute Inc, Cary, NC, pp 140 149

19. Calvo MS, Bell RR, Forbes RM 1982 Effect of protein-induced calciuria on calcium metabolism and bone status in adult rats. J Nutr 112:1401-1413

20. Allen LH, Wood RJ, Barlett RS 1983 Dietary protein level and skeletal development in the golden syrian hamster. Proc Soc Exp Biol Med 172:324329

21. Allen LH, Hall TE 1978 Calcium metabolism, intestinal calcium-binding protein, and bone growth of rats fed high protein diets. J Nutr 108:967-972

22. Bell RR, Englemann DT, Sie TL, Draper HH 1975 Effect of high protein intake on calcium metabolism in the rat. J Nutr 105:475-483

23. Petito SL, Evans JL 1984 Calcium status of the growing rat as affected by diet acidity from ammonium chloride, phosphate and protein. J Nutr 1 14:10491059

24. Howe JC, Beecher GR 1981 Effect of dietary protein and phosphorus levels on calcium and phosphorus metabolism of the young, fast growing rat. J Nutr 111:708-720

25. Anderson GH, Draper HH 1972 Effect of dietary phosphorus on calcium metabolism in intact and parathyroidectomized adult rats. J Nutr 102:11121132

26. Walser M 1971 Calcium-sodium interdependence in renal transport. In: Fisher JW (ed) Renal Pharmacology. Appleton-Century-Crofts, New York, pp 2141

27. Sutton RAL, Dirks JH 1978 Renal handling of calcium. Fed Proc 37:pt 2 2112-2119

28. Breslau NA, McGuire JL, Zerwekh JE, Pak CYC 1982 The role of dietary sodium on renal excretion and intestinal absorption of calcium and on vitamin D metabolism. J Clin Endocrinol Metab 55:369-373

29. Agus ZS, Gardner LB, Beck LH, Goldberg M 1973 Effects of parathyroid hormone on renal tubular reabsorption of calcium, sodium and phosphate. Am J Physiol 224:1143-1148 
30. Kendrick NC. Bishop CW. Deluca HF 1984 Multiple forms of vitamin Ddependent calcium binding protein in rat kidney. J Biol Chem 259:1269112695

31. Roth J, Brown D, Norman AW, Orci L 1982 Localization of the vitamin D dependent calcium-binding protein in mammalian kidney. Am J Physiol 243:F243-F252

32. Thomasset M, Parkes CO. Cuisinier-Gleizes 1982 Rat calcium-binding proteins: distribution, development, and vitamin D dependence. Am J Physio 243:E483-E488
33. Taylor AN McIntosh JE Bourdeau JE 1982 Immunocytochemical localization of vitamin D-dependent calcium-binding protein in renal tubules of rabbit. rat and chick. Kidney Int 21:765-773

34. Pansini AR Christakos S 1985 Cell-free translational analysis of messenger ribonucleic acid coding for vitamin D-dependent rat renal calcium-binding protein. Endocrinology 117:1652-1660

35. Pansini AR, Christakos S 1983 Evidence that sodium deprivation influences vitamin D-dependent rat renal calcium-binding protein. Life Sci 33:15671573

\section{Announcements \\ 11TH INTERNATIONAL CONVOCATION ON IMMUNOLOGY \\ Buffalo, NY, June 12-16, 1988 \\ Immunology and Immunopathology of the Alimentary Canal}

The Ernest Witebsky Center for Immunology will present this symposium in its regular biennial series at the Hyatt Regency Buffalo Hotel. Closed plenary sessions will focus on the topics: Basic Immunologic Considerations, Immunologically Responsive Tissue Cells, Immunopathologic Conditions (dental caries, periodontal disease, inflammatory bowel disease, celiac disease, gastrointestinal infections and infestations), Immune Response in Oral and Gastrointestinal Neoplasms, Nutritional Effects on the Immune Response, and Development of Vaccines. Open poster sessions for free contributions on the theme will be offered.

For further information contact: Dr. James F. Mohn, Director, Ernest Witebsky Center for Immunology, 240 Sherman Hall, State University of New York at Buffalo, Buffalo, New York 14214 (Telephone: 716-8312848).

\section{ANNUAL MEETING ABSTRACT DEADLINE}

The American Pediatric Society and the Society for Pediatric Research announce the abstract deadline for the 1988 Annual Meeting (May 2-6, Washington Sheraton Hotel, Washington D.C.) has been set as December 10, 1987. For further information contact: SPR-Debbie L. Wogenrich, The Society for Pediatric Research, 2350 Alamo S.E., Suite 106, Albuquerque, NM 87106, (505) 764-9099. APS-Dr. Audrey K. Brown, SecretaryTreasurer, Department of Pediatrics, Box 49, SUNY, Health Sciences Center at Brooklyn, 450 Clarkson Avenue, Brooklyn, NY 11203 (718) 270-1692. 